\title{
Grassland bird densities in seral stages of mixed-grass prairie
}

\author{
SHAWN C. FRITCHER, MARK A. RUMBLE, AND LESTER D. FLAKE
}

Authors are former Graduate Research Assistant (currently Area Resource Specialist Rice Lake State Park, Owatonna, MN), Wildlife and Fisheries Sciences, South Dakota State University, Brookings, S.D. 57007; Research Wildlife Biologist, Rocky Mountain Research Station, Rapid City, S.D. 57001; and Professor, Wildlife and Fisheries Sciences, South Dakota State University, Brookings, S. D. 57007.

Abstract

Birds associated with prairie ecosystems are declining and the ecological condition (seral stage) of remaining grassland communities may be a factor. Livestock grazing intensity influences the seral stage of grassland communities and resource managers lack information to assess how grassland birds are affected by these changes. We estimated bird density, species diversity, and species richness on 37 sites in 4 seral stages of western wheatgrass [Pascopyrum smithii (Rydb.) A. Löve]-green needlegrass [Nassella viridula (Trin.) Barkworth] communities of the Fort Pierre National Grassland. Bird species richness did not differ among seral stages $(P=\mathbf{0 . 5 7})$, but bird species diversity was greater $(\mathrm{P}<0.10)$ in early seral stages compared to late-intermediate seral stages. Grasshopper sparrow (Ammodramus savannarum Gmlin), bobolink (Dolichonyx oryzivorus Linnaeus), dickcissel (Spiza americana Gmlin), and brown-headed cowbird (Molothrus ater Boddaert) density increased $(P<0.10)$ from early to late seral stages. Burrowing owl (Athene cunicularia Molina), upland sandpiper (Bartramia longicauda Bechstein), chestnutcollared longspur (Calcarius ornatus Townsend), and horned lark (Eremophila alpestris Linnaeus) density decreased $(P<0.10)$ from early to late seral stages. Western meadowlarks (Sturnella neglecta Audubon) were more abundant in early $(P=0.05)$ and early-intermediate $(P=0.01)$ seral stages than late seral stages. Birds with habitat requirements including tall vegetation and residual cover were more abundant in later seral stages. Early seral stages were beneficial to birds that prefer short grass and sparse vegetative cover. Seral stage was an effective predictor of density for many bird species. A mosaic that includes all seral stages is necessary to maximize grassland bird species diversity and abundance across the landscape. Managers can assess the effects on grassland birds of management actions that alter the seral stage of the vegetation.

Key Words: Fort Pierre National Grassland, South Dakota, classification, range condition

Long-term data suggest that grassland bird populations are declining in the United States (Knopf 1994, Herkert 1995). Conversion of native grassland for agricultural purposes, invasion of alien plants, urban water development, and habitat fragmenta-

Research was funded by the Rocky Mountain Research Station, Rapid City, S.D. 57001 under Study Plan No. RC-931 Fort Pierre National Grassland, Pierre, S.D. 57501; and South Dakota State University, Brookings, S.D. 57007

Manuscript accepted 23 Sept. 03.

\section{Resumen}

Las aves asociadas a los ecosistemas de praderas estan declinando y la condición ecológica (etapa seral) de las comunidades remanentes de pastizal puede ser un factor de esta disminución. La intensidad de apacentamiento del ganado influye en la etapa seral de las comunidades de pastizal y los manejadores de los recursos carecen de información para evaluar como las aves del pastizal son afectadas por estos cambios. Estimamos la densidad de aves, y la diversidad y la riqueza de especies en 37 sitios en 4 etapas serales de comunidades de "Western wheatgrass" [Pascopyrum smithii (Rydb.) A. Löve]-"Green needlegrass" [Nassella viridula (Trin.) Barkworth] situadas en el Pastizal Nacional Fort Pierre. La riqueza de especies de aves no difirió entre etapas serales $(P=0.57)$, pero la diversidad de especies fue mayor $(P<0.10)$ en las etapas serales iniciales comparada con las etapas intermedias y finales. La densidad de "Grasshopper sparrow" (Ammodramus savannarum Gmlin), "Bobolink" (Dolichonyx oryzivorus Linnaeus), "Dickcissel” (Spiza americana Gmlin) y "Brown-headed cowbird" (Molothrus ater Boddaert) se incrementó de $(\mathbf{P}<\mathbf{0 . 1 0})$ de las etapas serales iniciales a las etapas serales finales. En cambio las densidades de "Burrowing owl" (Athene cunicularia Molina), "Upland sandpiper" (Bartramia longicauda Bechstein), "Chestnut-collared Iongspur" (Calcarius ornatus Townsend) y "Horned lark" (Eremophila alpestris Linnaeus) disminuyeron $(\mathrm{P}<0.10)$ de las etapas serales iniciales a las etapas finales. Los "Western meadowlarks" (Sturnella neglecta Audubon) fueron más abundantes en las etapas serales inicial $(P=0.05)$ e inicial-intermedia $(P=0.01)$ que en las etapas serales finales. Las aves con requerimientos de hábitat de vegetación alta y cobertura residual fueron mas abundantes en las etapas serales finales. Las etapas serales iniciales fueron benéficas para las aves que prefieren zacates cortos y vegetación dispersa. La etapa seral fue un predictor efectivo de la densidad de muchas especies de aves. Para maximizar la diversidad de especies de aves y la abundancia a través del paisaje se necesita un mosaico que incluya todas las etapas serales. Los manejadores pueden evaluar los efectos de las acciones de manejo que alteran la etapa seral de la vegetación sobre las aves del pastizal.

tion are apparent factors in the decline of grassland avifauna (Knopf and Samson 1995). The ecological condition of remaining grassland ecosystems has been altered by changes in grazing patterns, wildfire suppression, soil disturbances, and competition with alien plant species. Vegetative conditions of nonfederal rangelands suggest a high degree of alteration (USDA 1987). Grazing intensity influences grassland bird abundance (Owens 
and Myres 1973, Kantrud 1981, Kantrud and Kologiski 1982, Bock and Webb 1984) and seral condition (Brown and Schuster 1969, Ryder1980, Hart et al. 1988). Thus, seral stage may be a factor influencing grassland bird populations in Great Plains prairie landscapes.

The objectives of this study were to estimate grassland bird density, species richness, and species diversity in seral stages of western wheatgrass [Pascopyrum smithii (Rydb) A. Löve]-green needlegrass [Nassella viridula (Trin.) Barkworth] communities of the mixed-grass prairie. We also wanted to determine if seral stage was an adequate predictor of birds, or whether additional vegetative characteristics improved predictions of bird abundance. This information will enable managers to predict changes in grassland bird populations due to management actions that alter the seral stage of prairie vegetation.

\section{Study Area and Methods}

The study was conducted on the Fort Pierre National Grassland in central South Dakota (approx. $44^{\circ} 15^{\prime}$ north and $100^{\circ}$ $30^{\prime}$ west). The Fort Pierre National Grassland is 46,977 ha in size covering parts of Stanley, Lyman, and Jones counties. The area is situated within the Pierre Hills physiographic region (Johnson et al. 1995). Soils are primarily clays derived from Cretaceous Pierre Shale. Topography consists of flats cut by intermittent drainages and gently rolling hills. Elevation ranges from approximately 590 to $727 \mathrm{~m}$ above sea level. The climate is temperate with average temperatures ranging from $-4^{\circ} \mathrm{C}$ in winter to $23^{\circ} \mathrm{C}$ in summer. Mean annual precipitation is $460 \mathrm{~mm}$ with $43 \%$ occurring between March and June.

The area is characterized as a wheatgrass-needlegrass community within the mixed-grass prairie region (Küchler 1975). Dominant grasses of the area include western wheatgrass, green needlegrass, buffalo grass [Buchloe dactyloides (Nutt.) Engelm.], big bluestem (Andropogon gerardii Vitman), little bluestem [Schizachyrium scoparium (Michx.) Nash], sideoats grama [Bouteloua curtipendula (Michx.) Torr.], and blue grama [B. gracilis (Willd. ex Kunth) Lag. ex Griffiths]. Common forbs include western yarrow (Achillea millefolium L.), scarlet globemallow [Sphaeralcea coccinea (Nutt.) Rydb.], bracted spiderwort (Tradescantia bracteata Small ex Britt), fringed sagewort (Artemisia frigida
Willd.), cudweed sagewort (Artemisia ludoviciana Nutt.), black samson (Echinacea angustifolia DC), and prairie coneflower [Ratibida columnifera (Nutt.) Woot \& Standl.]. Scattered brush patches and trees occur mainly in drainages and include cherry (Prunus spp.), willows (Salix spp.), cottonwoods (Populus spp.), and western snowberry (Symphoricarpos occidentalis Hook).

During July and August of 1995, we identified 31 study sites that were representative of the 4 seral stages of wheatgrass-needlegrass communities on the Fort Pierre National Grassland. Six additional sites were selected during early spring 1996. At the time these sites were selected, we made a preliminary classification of seral stage on each using percent cover (Daubenmire 1959) multiplied by frequency of occurrence data for western wheatgrass, green needlegrass, and buffalo grass along 3 to 5 transects on the site. These data were then multiplied by the Fisher classification coefficients developed for wheatgrass-needlegrass communities of the Fort Pierre National Grassland using the methods developed by Uresk (1990) to classify seral stage on the site. We initially attempted to locate 10 sites in each seral stage. However, the distribution and area of early and late seral stages were limited and constrained our initial design. Each site was reclassified during late July to early August of 1996 and 1997 to make final seral stage assignments for the study (see below).

On each site, we established a transect that was positioned within the identified seral stage and made as long as possible (up to $400 \mathrm{~m}$ in length). Early and late seral stages were limited in size, abundance, and distribution, and thus, 4 transects in these seral stages were only 250 to $300 \mathrm{~m}$. A transect served as the experimental unit for our study design. We attempted to position the transects more than $200 \mathrm{~m}$ from fence lines, wetlands, roads, and other edges to minimize bias associated with these areas when estimating bird populations (Reese and Ratti 1988), but this was not always possible.

We counted birds from 15 May to 30 June of 1996 and 1997 along these transects. Bird counts began $1 / 2 \mathrm{hr}$ before sunrise, and were completed within 4 hours. While slowly $\left(\sim 1 \mathrm{~km} / \mathrm{hr}^{-1}\right)$ walking the transects, we recorded the species, sex, and perpendicular distance (to the nearest $m$ ) to the transect of all birds seen or heard. Birds were counted on each site for 2 consecutive days constituting 1 count session. Two count sessions were com- pleted during each year of the study on each site. Birds were not counted during periods of moderate to heavy rainfall (Manuwal and Carey 1991) or wind speed exceeding $5.5 \mathrm{~m} / \mathrm{sec}^{-1}$. (Erskine 1978, Mikol 1980). We used 2 observers during the bird counts. Observers were trained prior to bird counts to recognize birds in the area by site and sound. Observers counted different sites each count session to minimize bias from individual observers.

We combined data for both study years to obtain density estimates for breeding pairs of birds because we were interested in developing species habitat relations useful for rangeland managers in relation to long-term management objectives. Densities of breeding bird pairs (hereafter referred to as density) were estimated using the DISTANCE program (Laake et al. 1993). Perpendicular distance data were grouped in the DISTANCE program to minimize judgment errors (Bucklund et al.1993). We used the Akaike Information Criterion and Chi-Square goodness-of-fit tests to determine the most appropriate detection probability model for each species. Insufficient observations prevented development of detection probability functions for each bird species in each seral stage. Therefore, we developed a detection probability function for each species and assumed the shape of these functions were similar among all seral stages. We did not estimate density for birds with less than 30 observations or for species that this methodology is inappropriate (e.g., raptors, greater prairie chickens (Tympanuchus cupido Linnaeus), and sharptailed grouse (Tympanuchus phasianellus Linnaeus) were not included). Horned lark (Eremophila alpestris Linnaeus), grasshopper sparrow (Ammodramus savannarum Gmelin), chestnut-collared longspur (Calcarius ornatus Towsend), dickcissel (Spiza americana Gmelin), bobolink (Dolichonyx oryzivorus Linnaeus), western meadowlark (Sturnella neglecta Audubon), and red-winged blackbird (Agelaius phoeniceus Linnaeus) pair densities were estimated from the number of breeding males observed. Brown-headed cowbird density (Molothrus ater Boddaert) was estimated using the total number of all male birds observed regardless of whether the bird was singing or not. Because upland sandpipers (Bartramia longicauda Bechstein) are not sexually dimorphic, density was estimated by dividing the total number of birds observed by 2. Burrowing owl (Athene cunicularia Molina) density represents the density of indicated pairs, based on 
observed behavior. The multiple response permutation procedure (MRPP, Mielke 1984) with Bonferroni corrections to the $\alpha$-level to preserve experiment-wise error rates of multiple comparisons was used to test differences in bird densities, species richness, and species diversity among seral stages.

We characterized the vegetation structure of each site after completing daily bird counts. At $100-\mathrm{m}$ intervals along the main transect on each site, we established 3 to 5 transects $60 \mathrm{~m}$ in length (hereafter referred to as vegetation transects) that were perpendicular to, and centered on, the main transect. Visual obstruction measurements (VOM, Robel et al. 1970), representing the height in which $100 \%$ of a pole was obstructed from view, were recorded at the endpoints and at points located at 5-m intervals along these vegetation transects. At each point, vegetation height was recorded as the height that vegetation contacted a $30-\mathrm{cm}$ diameter plexiglass disc lowered over the pole (Higgins and Barker 1982), and litter depth was measured using a ruler lowered through the litter layer.

During July and August of each year, we characterized vegetation composition at each site. We estimated percent canopy cover (Daubenmire 1959) of total grasses, total forbs, bare ground, litter, western wheatgrass, green needlegrass, buffalo grass, and yellow sweet clover [Melilotus officinalis (L.) Lam.] in thirty, 0.10- $\mathrm{m}^{2}$ quadrats spaced at 2-m intervals along the vegetation transects. We calculated an index of vegetation composition using percent canopy cover times frequency of occurrence for western wheatgrass, green needlegrass, and buffalo grass for each transect. The average values for these indices were applied to the discriminant function classification coefficients to determine seral stage (Uresk 1990; unpubl. rep., USDA For. Serv., Rocky Mtn. Res. Stn., Rapid City, S.D.). We calculated the coefficient of variation for VOM, vegetation height, and litter depth to characterize vegetation heterogeneity (Rotenberry and Wiens 1980) for each transect, and averaged these for each site.

Initial vegetation analyses suggested that vegetation variables were not independent among seral stages. Therefore, we used principal component analysis to identify the groups of vegetation variables that responded similarly among seral stages. We then used multivariate MRPP analyses using BLOSSOM statistical software (Slauson et al. 1991) to test for differences in groups of vegetation variables among seral stages. We applied a step-down multiple comparison procedure that maintained the predetermined $\alpha$-level for multiple comparisons among seral stages for these tests (Petrondas and Gabriel 1983).

Multiple, linear regression was used to assess the effectiveness of seral stage versus vegetation characteristics as predictors of bird species density on these grassland sites. Independent variables with $\mathrm{k}$ categories can be modeled using k-1 dummy regressors (Fox 1997). We developed 3 dummy variables representing contrasts between the early and other seral stages. These dummy regressors were forced into the regression model while allowing vegetation variables to enter into the model using a step-wise technique. This procedure holds variation accounted for by seral stage regressors constant while allowing vegetation variables to enter the model when they significantly add to the reduction in the sum of squares due to regression. The model estimates different intercept coefficients for each seral stage but common slope coefficients for each continuous variable. Independent vegetation variables considered in these analyses included VOM, litter depth, percent forb cover, and percent bare ground cover. We applied $\log$ transformations to the density estimates of some bird species and vegetation variables to meet the assumption of normal distributions. Plots of residuals and

Table 1. Mean ( \pm SE) of vegetation variables in seral stages of mixed-grass prairie on Fort Pierre National Grassland, South Dakota 1996 and $1997 .{ }^{1}$

\begin{tabular}{|c|c|c|c|c|}
\hline \multirow[b]{2}{*}{ Vegetation Variable ${ }^{2.3}$} & \multicolumn{4}{|c|}{ Seral Stage } \\
\hline & $\begin{array}{l}\text { Early } \\
\bar{X} \pm S E\end{array}$ & $\begin{array}{c}\text { Early-intermediate } \\
\bar{X} \pm S E\end{array}$ & $\begin{array}{l}\text { Late-intermed } \\
\overline{\mathrm{X}} \pm \mathrm{SE} \pm\end{array}$ & $\begin{array}{l}\text { Late } \\
\bar{X} \pm S E\end{array}$ \\
\hline \multicolumn{5}{|l|}{ Percent canopy cover } \\
\hline Western wheatgrass & $39.1 \pm 2.8 \mathrm{~A}$ & $44.0 \pm 6.8 \mathrm{~B}$ & $73.7 \pm 2.0 \mathrm{C}$ & $42.9 \pm 7.1 \mathrm{D}$ \\
\hline Buffalo grass & $68.2 \pm 2.2 \mathrm{~A}$ & $25.4 \pm 5.7 \mathrm{~B}$ & $9.8 \pm 2.0 \mathrm{C}$ & $6.9 \pm 1.6 \mathrm{D}$ \\
\hline Green needlegrass & $1.1 \pm 0.5 \mathrm{~A}$ & $6.5 \pm 3.1 \mathrm{~B}$ & $10.3 \pm 1.7 \mathrm{C}$ & $57.4 \pm 0.9 \mathrm{D}$ \\
\hline Total grasses & $90.5 \pm 1.0$ & $85.7 \pm 3.5$ & $91.3 \pm 0.5$ & $91.6 \pm 1.3$ \\
\hline Forbs & $18.0 \pm 2.0$ & $26.1 \pm 4.6$ & $19.3 \pm 1.7$ & $19.2 \pm 2.5$ \\
\hline Bare ground & $10.7 \pm 2.3$ & $12.9 \pm 6.6$ & $7.1 \pm 1.7$ & $1.8 \pm 0.4$ \\
\hline Litter & $80.7 \pm 3.1$ & $81.3 \pm 7.1$ & $87.2 \pm 2.1$ & $94.6 \pm 0.6$ \\
\hline \multicolumn{5}{|c|}{ Percent frequency of occurrence } \\
\hline Western wheatgrass & $91.3 \pm 3.1 \mathrm{~A}$ & $95.7 \pm 4.0 \mathrm{~B}$ & $98.0 \pm 1.3 \mathrm{C}$ & $95.4 \pm 1.7 \mathrm{C}$ \\
\hline Buffalo grass & $84.1 \pm 6.8 \mathrm{~A}$ & $54.7 \pm 12.28 \mathrm{~B}$ & $30.3 \pm 4.5 \mathrm{C}$ & $33.2 \pm 6.4 \mathrm{C}$ \\
\hline Green needlegrass & $3.0 \pm 1.25 \mathrm{~A}$ & $12.6 \pm 3.7 \mathrm{~B}$ & $38.8 \pm 6.7 \mathrm{C}$ & $60.4 \pm 15.4 \mathrm{C}$ \\
\hline Vegetation height $(\mathrm{cm})$ & $26.6 \pm 2.3 \mathrm{~A}$ & $35.3 \pm 4.5 \mathrm{~A}$ & $45.0 \pm 1.5 \mathrm{~B}$ & $51.8 \pm 2.8 \mathrm{~B}$ \\
\hline Vegetation height $\mathrm{CV}$ & $39.1 \pm 2.6 \mathrm{~A}$ & $34.1 \pm 2.6 \mathrm{~A}$ & $26.6 \pm 1.0 \mathrm{~B}$ & $27.4 \pm 2.4 \mathrm{~B}$ \\
\hline Litter depth (cm) & $0.9 \pm 0.1 \mathrm{~A}$ & $1.4 \pm 0.3 \mathrm{~A}$ & $2.5 \pm 0.2 \mathrm{~B}$ & $3.1 \pm 0.1 \mathrm{~B}$ \\
\hline Litter depth CV & $96.4 \pm 6.3 \mathrm{~A}$ & $101.4 \pm 11.0 \mathrm{~A}$ & $67.0 \pm 5.0 \mathrm{~B}$ & $44.1 \pm 5.0 \mathrm{~B}$ \\
\hline $\operatorname{VOM}(\mathrm{cm})$ & $5.8 \pm 1.0 \mathrm{~A}$ & $8.6 \pm 1.5 \mathrm{~A}$ & $14.5 \pm 1.0 \mathrm{~B}$ & $17.0 \pm 1.8 \mathrm{~B}$ \\
\hline VOM CV & $86.2 \pm 7.3 \mathrm{~A}$ & $72.2 \pm 9.8 \mathrm{~A}$ & $44.5 \pm 2.2 \mathrm{~B}$ & $41.2 \pm 2.9 \mathrm{~B}$ \\
\hline
\end{tabular}

${ }^{1}$ Rows of means followed by different letters are significantly different $(P<0.10)$ using multivariate MRPP with stepdown tests (Petrondas and Gabriel 1983).

${ }^{2} \mathrm{CV}=$ coefficient of variation; VOM = visual obstruction measurement.

${ }^{3}$ Groups of variable separated by lines were analyzed together in MRPP. analysis diagnostics were examined to assess the assumptions of the regression analysis and to determine if any outliers were present in our analyses.

Scientific names of plants are from the USDA-NRCS (1999) and scientific names for birds are from the American Ornithologists' Union (1999). Statistical significance was determined at $\alpha=0.10$ and all multiple range tests preserve experiment-wise error rates at that alpha level.

\section{Results}

Seral stage of some sites changed from our initial selection, and our final classification had 7 sites in the early, 6 in the early-intermediate, 18 in the late-intermediate, and 6 in the late seral stage. Percent composition and frequency of occurrence wheatgrass, buffalo grass, and stages (Table 1) Percent can frequency of buffalo grass were highest on early seral sites and declined as succession progressed toward the late seral stage. Frequency and cover of western wheatgrass increased as seral stage changed from early to late-intermediate, then declined slightly in the late seral stage. Frequency and cover of green needlegrass increased from early to late seral stages. Nonetheless, statistical patterns of differ- 
ences for frequency and canopy cover among seral stages for these 3 species were slightly different. Percent canopy cover of total grasses, total forbs, bare ground, and litter were similar among seral stages. Late-intermediate and late seral stages had taller, more dense vegetation, and greater litter layers than early and early-intermediate seral stages. Vegetation patchiness (CV's) was greater in early and early-intermediate seral stages compared to late-intermediate and late seral stages. Six of the early sites and 2 of the early-intermediate sites were blacktailed prairie dog (Cynomys ludovicianus Ord) towns, possibly confounding some relations between plants and birds. Prairie dogs seem to be an important factor in maintaining the dominance of buffalo grass that delineates the early seral stage. Because prairie dog towns are an integral part of the prairie ecosystem and essentially represent the largest areas of early seral stage conditions on the Fort Pierre National Grassland, they were included in all analyses as the seral stage in which they were classified.

Thirty-eight bird species were counted on transects during the study. Grasshopper sparrows, western meadowlarks, brownheaded cowbirds, and chestnut-collared longspurs were the most abundant bird species, composing $76 \%$ of the birds. Other common species included the redwinged blackbird, bobolink, upland sandpiper, horned lark, lark bunting (Calamospiza melanocorys Stejneger), and marbled godwit (Limosa fedoa Linnaeus). Bird species richness did not differ among seral stages (Table 2). Bird species diversity was greater in the early seral stage compared to the late-intermediate seral stage.

Grasshopper sparrows, dickcissels, bobolinks, and brown-headed cowbirds were generally more abundant in the later seral stages than in the earlier seral stages. Horned lark, chestnut-collared longspur, upland sandpiper, and burrowing owl densities tended to be greater in the earlier seral stages than in the later seral stages (Table 2). Western meadowlarks were common in all seral stages, but were more abundant in the early and early-intermediate seral stages than on late seral sites.

Grasshopper sparrow, brown-headed cowbird, burrowing owl, and upland sandpiper densities were best predicted using seral stages in our study (Table 3 ). Coefficients of multiple determination $\left(R^{2}\right)$ ranged from 0.13 to 0.43 and no vegetation variables entered the regression models for these species. Regression mod-

Table 2. Mean ( \pm SE) density of male birds per 10 ha in seral stages of mixed-grass prairie on Fort Pierre National Grassland, South Dakota 1996 and 1997.'

\begin{tabular}{|c|c|c|c|c|}
\hline \multirow[b]{3}{*}{ Bird Species } & \multicolumn{4}{|c|}{ Seral Stage } \\
\hline & Early & Early-intermediate & Late-intermediat & te Late \\
\hline & $\bar{X} \pm S E$ & $\bar{X} \pm S E$ & $\bar{X} \pm S E \pm$ & $\bar{X} \pm S E$ \\
\hline Species richness & $14.70 \pm 1.57$ & $13.0 \pm 1.32$ & $12.4 \pm 0.75$ & $14.5 \pm 1.43$ \\
\hline Species diversity & $0.88 \pm 0.05 \mathrm{~A}$ & $0.80 \pm 0.02 \mathrm{AB}$ & $0.73 \pm 0.02 \mathrm{~B}$ & $0.73 \pm 0.04 \mathrm{AB}$ \\
\hline Horned lark & $1.41 \pm 0.53 \mathrm{~A}$ & $0.88 \pm 0.53 \mathrm{~A}$ & $0.03 \pm 0.02 B$ & $0.0 \pm 0.0 \mathrm{AB}$ \\
\hline Grasshopper sparrow & $1.57 \pm 0.59 \mathrm{~A}$ & $4.26 \pm 1.14 \mathrm{AB}$ & $6.26 \pm 0.59 \mathrm{~B}$ & $7.97 \pm 0.84 \mathrm{~B}$ \\
\hline Chestnut-collared longspur & $5.02 \pm 1.84 \mathrm{~A}$ & $4.88 \pm 1.63 \mathrm{~A}$ & $1.10 \pm 0.54 \mathrm{~B}$ & $0.20 \pm 0.11 \mathrm{AB}$ \\
\hline Dickcissel & $0.04 \pm 0.04 \mathrm{AB}$ & $0.0 \pm 0.0 \mathrm{~A}$ & $0.06 \pm 0.03 \mathrm{~A}$ & $0.61 \pm 0.30 \mathrm{~B}$ \\
\hline Bobolink & $0.04 \pm 0.04 \mathrm{~A}$ & $0.09 \pm 0.07 \mathrm{~A}$ & $0.86 \pm 0.16 \mathrm{~B}$ & $0.43 \pm 0.10 \mathrm{~B}$ \\
\hline Western meadowlark & $4.74 \pm 0.50 \mathrm{~A}$ & $4.95 \pm 0.79 \mathrm{~A}$ & $4.07 \pm 0.27 \mathrm{AB}$ & $3.38 \pm 0.14 \mathrm{~B}$ \\
\hline Red-winged blackbird & $0.78 \pm 0.26$ & $0.43 \pm 0.22$ & $0.66 \pm 0.20$ & $0.20 \pm 0.08$ \\
\hline Brown-headed cowbird & $1.55 \pm 0.54 \mathrm{~A}$ & $1.82 \pm 0.39 \mathrm{AB}$ & $3.24 \pm 0.30 \mathrm{~B}$ & $2.58 \pm 0.30 \mathrm{AB}$ \\
\hline Upland sandpiper & $1.37 \pm 0.81 \mathrm{AB}$ & $0.63 \pm 0.29 \mathrm{~A}$ & $0.22 \pm 0.07 \mathrm{AB}$ & $0.03 \pm 0.03 B$ \\
\hline Burrowing owl & $0.75 \pm 0.22 \mathrm{~A}$ & $0.19 \pm 0.19 \mathrm{AC}$ & $0.03 \pm 0.02 \mathrm{BC}$ & $0.0 \pm 0.0 \mathrm{AB}$ \\
\hline
\end{tabular}

Rows of densities followed by different letters are significantly different $(\mathrm{P}<0.10)$ using MRPP tests.

els for bobolinks, dickcissels, chestnutcollared longspurs, and horned larks included both seral stage regressors and vegetation variables. When vegetation variables entered the regression models for bobolinks, chestnut-collared longspurs, and horned larks, the seral stage regressors lost significance. For example, bobolink density was initially modeled using seral stage contrast variables early versus earlyintermediate (D2) and early versus lateintermediate (D3) having significant Pvalues of $P=0.01$ and $P=0.06$, respectfully. When the vegetation variables litter depth and bare ground entered the regression equation (Final Model, Table 3), these variables became nonsignificant $P=$ 0.32 and $P=0.71$ for early versus earlyintermediate and early versus late-intermediate, respectively. Seral stage regressors were not effective in modeling densities for western meadowlarks or red-winged blackbirds.

\section{Discussion}

The concept that wildlife densities are related to plant succession and recognizable seral stages is fundamental to wildlife management (Robinson and Bolen 1984, Christensen and Davis 1986). Both vegetation structure and composition differed among seral stages of wheatgrass-needlegrass communities on the Fort Pierre National Grassland. Later seral stages provided habitat conditions favorable to species that require taller and more dense cover with deeper litter layers. Grasshopper sparrows preferred late-intermediate and late seral stages and were nearly absent on early seral sites. Wheatgrass and needlegrass areas provide suitable grasshopper sparrow habitat in the Great Plains (Kantrud and Kologiski 1982). Grasshopper sparrows are positively associated with vegetation height and density in short to mixed-grass prairie (Rotenberry and Wiens 1980).

Bobolink and dickcissel densities on the Fort Pierre National Grassland were lower than reported in other prairie areas (Bollinger and Gavin 1992, Rotenberry and Wiens 1980, Wiens 1969). On the Fort Pierre National Grassland, bobolinks had greatest densities in later seral stages. Bobolinks are associated with tall, dense vegetation (Wiens 1969, Renken and Dinsmore 1987) and with increased litter (Tester and Marshall 1961). Dense nesting cover for waterfowl (Renken and Dinsmore 1987), hayfields, and tame grass pastures (Kendeigh 1941, Kantrud 1981, Bollinger and Gavin 1992) are also considered favorable habitats for bobolinks. Madden (1996) suggested that the preference of bobolinks for exotic grasses and hayfields in the northern Great Plains may be due to their affinity for tall grass prairie. Dickcissels were most abundant on late seral sites. Dickcissels are more common in eastern tall grass prairie compared to western prairies in South Dakota (South Dakota Ornithologists' Union 1991). Density of dickcissels was notably high on 2 study sites in 1996, presumably due to the abundance of yellow sweet clover, which may have been important for nesting (Overmire 1962, Harmeson 1974, Wiens 1969). Regionally, the Fort Pierre National Grassland does not support large populations of bobolinks or dickcissels, but locally late-intermediate and late seral stages are important habitats for these species. 
Table 3. Multiple regression models generated to assess the relative effectiveness of seral stage versus vegetation characteristics as predictors of bird species density on Fort Pierre National Grassland, SD 1996 and 1997. D1, D2, and D3 are dummy-coded variables which represent the categorical variable seral stage. Dummy variables were forced into the model and multiple models are reported when vegetation variables enter the model using a step-wise technique. If the dummy variables did not generate a significant model then only vegetation variables were used in the regression analysis.

\begin{tabular}{|c|c|c|c|c|c|c|}
\hline \multirow{3}{*}{$\begin{array}{l}\text { Dependent } \\
\text { variable }\end{array}$} & \multicolumn{3}{|c|}{ Model Summary } & \multirow[b]{2}{*}{ Independent $^{1}$} & \multicolumn{2}{|c|}{ Coefficient Summary } \\
\hline & Adjusted & SE of & & & & \\
\hline & $\mathrm{R}^{2}$ & estimate & Significance & variables & $B( \pm \mathrm{SE})$ & Significance \\
\hline \multirow[t]{3}{*}{ Horned lark (seral stages only) } & 0.41 & 0.71 & $<0.01$ & Dl & $-0.30(0.40)$ & 0.46 \\
\hline & & & & D2 & $-1.37(0.32)$ & $<0.01$ \\
\hline & & & & D3 & $-1.57(0.40)$ & $<0.01$ \\
\hline \multirow[t]{4}{*}{ Horned lark (final model) } & 0.50 & 0.66 & $<0.01$ & D1 & $-0.08(0.38)$ & 0.84 \\
\hline & & & & D2 & $-0.70(0.39)$ & 0.09 \\
\hline & & & & D3 & $-0.68(0.50)$ & 0.18 \\
\hline & & & & Litter Depth & $-2.16(0.82)$ & 0.01 \\
\hline \multirow[t]{3}{*}{ Grasshopper sparrow (final model) } & 0.43 & 0.24 & $<0.01$ & D1 & $0.27(0.13)$ & 0.05 \\
\hline & & & & D2 & $0.47(0.02)$ & $<0.01$ \\
\hline & & & & D3 & $0.64(0.13)$ & $<0.01$ \\
\hline \multirow[t]{3}{*}{ Chestnut-collared longspur (seral stages only) } & 0.21 & 0.81 & 0.01 & D1 & $0.03(0.45)$ & 0.94 \\
\hline & & & & D2 & $-0.92(0.36)$ & 0.02 \\
\hline & & & & D3 & $-1.12(0.45)$ & 0.02 \\
\hline \multirow[t]{5}{*}{ Chestnut-collared longspur (final model) } & 0.45 & 0.68 & $<0.01$ & D1 & $0.40(0.39)$ & 0.31 \\
\hline & & & & D2 & $-0.60(0.32)$ & 0.07 \\
\hline & & & & D3 & $-0.41(0.44)$ & 0.36 \\
\hline & & & & Bare Ground & $0.99(0.33)$ & 0.01 \\
\hline & & & & $\%$ Forbs & $-2.15(0.72)$ & 0.01 \\
\hline \multirow[t]{3}{*}{ Dickcissel (seral stages only) } & 0.13 & 0.67 & 0.06 & D1 & $-0.21(0.37)$ & 0.57 \\
\hline & & & & D2 & $0.10(0.30)$ & 0.75 \\
\hline & & & & D3 & $0.82(0.37)$ & 0.03 \\
\hline \multirow[t]{4}{*}{ Dickcissel (final model) } & 0.22 & 0.63 & 0.02 & D1 & $-0.42(0.36)$ & 0.26 \\
\hline & & & & D2 & $0.08(0.28)$ & 0.79 \\
\hline & & & & D3 & $0.78(0.35)$ & 0.04 \\
\hline & & & & $\%$ Forbs & $1.45(0.67)$ & 0.04 \\
\hline \multirow[t]{3}{*}{ Bobolink (seral stages only) } & 0.36 & 0.13 & $<0.01$ & D1 & $0.02(0.07)$ & 0.79 \\
\hline & & & & D2 & $0.23(0.06)$ & $<0.01$ \\
\hline & & & & D3 & $0.14(0.07)$ & 0.06 \\
\hline \multirow[t]{5}{*}{ Bobolink (final model) } & 0.58 & 0.10 & $<0.01$ & D1 & $-0.04(0.06)$ & 0.47 \\
\hline & & & & D2 & $0.06(0.06)$ & 0.32 \\
\hline & & & & D3 & $-0.03(0.08)$ & 0.71 \\
\hline & & & & Litter Dept & $0.397(0.16)$ & $<0.01$ \\
\hline & & & & Bare Ground & $0.020(0.06)$ & $<0.01$ \\
\hline Westewn meadowlark (final model) & 0.15 & 0.12 & 0.01 & Litter Depth & $-0.27(0.10)$ & 0.01 \\
\hline Red-winged Blackbird (final model) & $\begin{array}{ll}---- \\
\end{array}$ & $-\cdots$ & NS & 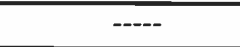 & $\begin{array}{ll}---- \\
--1\end{array}$ & NS \\
\hline \multirow[t]{3}{*}{ Brown-headed cowbird (final model) } & 0.22 & 0.12 & 0.01 & D1 & $0.03(0.07)$ & 0.68 \\
\hline & & & & D2 & $0.17(0.05)$ & $<0.01$ \\
\hline & & & & D3 & $0.10(0.07)$ & 0.13 \\
\hline \multirow[t]{3}{*}{ Upland sandpiper (final model) } & 0.13 & 0.46 & 0.05 & D1 & $-0.04(0.26)$ & 0.87 \\
\hline & & & & D2 & $-0.37(0.21)$ & 0.08 \\
\hline & & & & D3 & $-0.64(0.26)$ & 0.02 \\
\hline \multirow{3}{*}{ Burrowing owl (final model) } & 0.49 & 0.57 & $<0.01$ & D1 & $-1.26(0.32)$ & $<0.01$ \\
\hline & & & & D2 & $-1.44(0.25)$ & $<0.01$ \\
\hline & & & & D3 & $-1.60(0.32)$ & $<0.01$ \\
\hline
\end{tabular}

$\mathrm{D} 1=$ contrast between early and early-intermediate seral stage; $\mathrm{D} 2$ = contrast between early and late-intermediate seral stage;

D3 = confrast between early and late seral stage.

Early and early-intermediate seral stages supported species that require shorter and more sparse vegetative conditions. Chestnut-collared longspur and horned lark habitat typically consists of short, less dense vegetation (Owens and Myres 1973, Kantrud 1981, Wyckoff 1986, Wiens 1973). This helps explain why chestnutcollared longspur density was 25 times greater in the early seral stage compared to the late seral stage $(P=0.12)$. Considering the magnitude of the difference in density and its effect on breeding potential, the difference is most likely biologically important (e.g., Stiedl et al. 1997).

Burrowing owls in the Great Plains region are associated with prairie dog towns (Agnew et al. 1986) and we assume the differences in density estimates of burrowing owls among seral stages were due to the presence of prairie dog burrows on early and early-intermediate seral sites. Prairie dog burrows provide nest sites and escape corridors for burrowing owls
(MacCracken et al. 1985). Burrowing owls will use areas of low grass cover and burrows of other mammals (Bue 1955, Martin 1973). On the Fort Pierre National Grassland, prairie dog towns comprised 10 of the 13 early and early-intermediate seral sites. Prairie dog towns are probably required for maintaining burrowing owl populations on the Fort Pierre National Grassland.

Early and early-intermediate seral stages on the Fort Pierre National Grassland are 
important upland sandpiper feeding habitats, whereas late-intermediate and late seral conditions are likely important for nesting activities. Upland sandpipers nest in dense vegetative cover $<20.5 \mathrm{~cm}$ tall (Higgins et al. 1969), but feed in short, sparse grass vegetation (Ailes 1976). Our bird counts were conducted in the morning when our observations indicated the upland sandpipers were feeding. Thus, we suspect upland sandpipers used early seral stage sites mainly for feeding. Upland sandpipers were uncommon on the early seral sites during the afternoon when vegetation structure measurements were being collected. We found 2 upland sandpiper nests and both were in late-intermediate or late seral stage sites.

Western meadowlarks are habitat generalists with a tolerance to a wide range of grassland habitats (Owens and Myres 1973, Rotenberry and Wiens 1980, Agnew et al. 1986). Grazing had little effect on western meadowlark abundance in North Dakota grasslands (Kantrud 1981). However, western meadowlarks are less abundant in areas where the vegetation becomes too tall and dense (Wiens 1969, Madden 1996). On the Fort Pierre National Grassland, tall dense vegetation, characteristic of late seral sites, was less occupied by western meadowlarks. Redwinged blackbirds are typically considered a wetland or wet meadow associated species that often nests in shrubs over dry land (South Dakota Ornithologists' Union 1991). Red-winged blackbird density was low in all seral stages and field observations suggest that density was most likely influenced by the proximity of the nearest wetland area rather than the seral stage of prairie vegetation.

Density of grasshopper sparrows, brown-headed cowbirds, burrowing owls, and upland sandpipers on the Fort Pierre National Grassland were predicted using only seral stage regressors. The step-wise addition of vegetation variables did not improve predictive ability of the regression models. Bobolinks, dickcissels, chestnut-collared longspurs, and horned larks were best predicted by including some vegetation variables in the regression models. With the exceptions of meadowlarks and red-winged blackbirds, each of the bird species above exhibited significant rank correlations to variables that reflected vegetation. Of those species that exhibited rank correlations to vegetation height, dickcissels alone lacked significant correlations to measures of patchiness in vegetation height. Nonetheless, when seral stage was entered into the regression equa- tions, none of the species we evaluated showed significant correlations to measures of vegetation height or patchiness suggesting that for these species in needlegrass-wheatgrass communities of central South Dakota, seral stage was an adequate predictor of their habitat conditions. For those birds that vegetation variables entered the regression models after seral stage, the seral stage regressors often lost significance, demonstrating that there were confounding effects between vegetation variables and seral stage regressors. As a result, for some bird species it is difficult to determine whether seral stage was an adequate predictor of bird species density.

Numerous factors need to be considered when developing habitat models to facilitate management decisions. A large amount of the variability in bird densities remained unexplained regardless of the variables included. Territoriality, available nest sites, foraging opportunities, site tenacity, predation, or landscape features may be important determinants of the unexplained variation for these models. Managers must weigh the increased costs of measuring additional variables included in a model against the benefits of increased predictive ability. Models are satisfactory when they allow managers to make informed decisions. Habitat models do not need to depict reality, but rather simplify it (Starfield 1997). Managing rangelands with seral stages provides the manager with a unit of measure to determine objectives and to evaluate the effects of management (Dyksterhuis 1985, Uresk 1990). On a coarse scale, seral stage models may provide enough information about bird densities to facilitate management decisions, but specific vegetation measurements may be needed when making more finite habitat decisions for individual species.

\section{Conclusions}

On the Fort Pierre National Grassland, each of the 4 seral stages was important for grassland birds. A mosaic of seral stages should be maintained across the Fort Pierre National Grassland landscape to provide habitat for all grassland birds. Landscape issues such as fragmentation should be better investigated to determine appropriate seral stage patch size and distribution. Seral stage was an effective predictor of density for many grassland birds in this study. Seral stages provide an ecological framework for developing management plans and predicting effects of management decisions on grassland bird popu- lations. We are not suggesting that vegetation structure and composition are unimportant in describing bird habitat relations. Vegetation structure (Wiens 1973, Rotenberry and Wiens 1980) and plant taxonomic composition (Wiens and Rotenberry 1981, Rotenberry 1985, Knopf et al. 1990) are important determinants for grassland birds. The concepts of seral stage versus vegetation structure or vegetation composition as predictors of grassland bird density are not mutually exclusive. Floristic composition was used to determine seral stage in our study. Additionally, plant forms and growth strategies provided inherent differences in vegetation structure among seral stages. Vegetation measurements are often tedious, time consuming, and costly to collect. Seral stages may provide managers with an efficient and functional tool from which multiple use management decisions can be made, including the development and monitoring of grassland bird management objectives.

\section{Literature Cited}

Agnew, W., D.W. Uresk, and R.M. Hansen. 1986. Flora and fauna associated with prairie dog colonies and adjacent ungrazed mixedgrass prairie in western South Dakota. J. Range Manage. 39:135-138.

Ailes, I.W. 1976. Ecology of the upland sandpiper in central Wisconsin. M.S. Thesis. Univ. Wisconsin, Stevens Point, Wis.

American Ornithologists' Union. 1999. The A.O.U. check-list of North American Birds, seventh edition. Available at: http://pica.wru.edu/AOU/birdlist.HTML. Accessed 18 June 2000.

Bock, C.E. and B. Webb. 1984. Birds as grazing indicator species in southeastern Arizona. J. Wildl. Manage. 48:1045-1049.

Bollinger, E.K. and T.A. Gavin. 1992. Eastern bobolink populations: Ecology and conservation in an agricultural landscape, $p$. 497-506. In: J.M. Hagan and D.W. Johnson (eds.) Ecology and conservation of neotropical migrant landbirds. Smithsonian Institution Press, Washington, D.C.

Brown, J.W. and J.L. Schuster. 1969. Effects of grazing on a hardland site in the Southern High Plains. J. Range Manage. 22:418-423.

Buckland, S.T., D.R. Anderson, K.P. Burnham, and J.L. Laake. 1993. Distance sampling: Estimating abundance of biological populations. Chapman and Hall. London, England.

Bue, G.T. 1955. Recent observations of burrowing owls in Lyon and Yellow Medicine counties, Minnesota. Flicker 27:40-41.

Christensen, N.L. and L.D. Davis. 1986. Introduction: Linking wildlife models with models of vegetation succession, p. 337. In: J. Verner, M.L. Morrison, and C.J. Ralph 
(eds.) Wildlife 2000. Univ. Wis. Press, Madison, Wis.

Daubenmire, R. 1959. A canopy-coverage method of vegetation analysis. Northwest Sci. 33:43-64.

Dyksterhuis, E.J. 1985. Follow-up on range sites and condition classes as based on quantitative ecology. Rangelands 7:172-173.

Erskine, A.J. 1978. The first ten years of the cooperative breeding bird survey in Canada. Can. Wildl. Serv. Rep. Ser. No. 42.

Fox, J. 1997. Applied regression analysis, linear models, and related methods. Sage Publications, Thousand Oaks, Calif.

Harmeson, J.P. 1974. Breeding ecology of the dickcissel. Auk 91:348-359.

Hart, R.H., M.J. Samuel, P.S. Test, and M.A. Smith. 1988. Cattle, vegetation, and economic responses to grazing systems and grazing pressure. J. Range Manage. 41:282-286.

Herkert, J.R. 1995. An analysis of midwestern breeding bird population trends: 1966-1993. Amer. Midl. Nat. 134:41-50.

Higgins, K.F. and W.T. Barker. 1982. Changes in vegetation structure in seeded nesting cover in the prairie pothole region. U.S. Dept. Int., Fish and Wildl. Serv., Special Sci. Rep. Wildl. No. 242. Washington, D.C.

Higgins, K.F., H.F. Duebbert, and R.B. Oetting. 1969. Nesting of the upland sandpiper on the Missouri Coteau. Prairie Nat. $1: 45-48$.

Johnson, R.R., K.F. Higgins, and D. E. Hubbard. 1995. Using soils to delineate South Dakota physiographic regions. Great Plains Res. 5:309-322.

Kantrud, H.A. 1981. Grazing intensity effects on the breeding avifauna of North Dakota native grasslands. Can. Field Nat. 95:404-417.

Kantrud, H.A. and R.L. Kologiski. 1982. Effects of soils and grazing on breeding birds of uncultivated upland grasslands of the northern Great Plains. U.S. Dept. Int., Fish and Wildl. Serv., Wildl. Res. Rep. No. 15.

Kendeigh, S.C. 1941. Birds of a prairie community. Condor 43:165-174.

Knopf, F.L. 1994. Avian assemblages on altered grasslands. Studies in Avian Biology 15:247-257.

Knopf, F.L, and F.B. Samson. 1995. Conserving the biotic integrity of the Great Plains, p. 121-133. In: S.R. Johnson and A. Bouzaher (eds.) Conservation of Great Plains Ecosystems. Kluwer Publishers, The Netherlands.

Knopf, F.L., J.A. Sedgwick, and D.B. Inkley. 1990. Regional correspondance among shrubsteppe bird habitats. Condor 92:45-53.

Küchler, A.W. 1975. Potential natural vegetation of the coterminous United States. Amer. Geo. Soc. N.Y. Spec. Pub. 36.

Laake, J.L., S.T. Buckland, D.R. Anderson, and K.P. Burnham. 1993. DISTANCE user's guide V2.0. Colo. Coop. Fish and Wildl. Res. Unit, Colo. State Univ., Fort Collins, Colo.
MacCracken, J.G., D.W. Uresk, and R.M. Hansen. 1985. Vegetation and soils of burrowing owl nest sites in Conata Basin, South Dakota. Condor 87:152-154.

Madden, E.M. 1996. Passerine communities and bird-habitat relationships on prescribeburned, mixed-grass prairie in North Dakota. M.S. Thesis, Mont. State Univ. Bozeman, Mont.

Manuwal, D.A. and A.B. Carey. 1991. Methods for measuring populations of small diurnal forest birds. Gen. Tech. Rep. PNM278. USDA For. Serv. Pacific Northwest Res. Stn., Portland, Ore.

Martin, D.J. 1973. Selected aspects of burrowing owl ecology and behavior. Condor 75:446-456.

Mielke, P.W. 1984. Meteorological applications of permutation techniques based on distance functions. Handbook Statistics 4:813-830.

Mikol, S.A. 1980. Field guidelines for using transects to sample nongame bird populations. U.S. Dept. Int., Fish and Wildl. Serv. Biol. Survey Program. FWS/OBS-80/85.

Overmire, T.G. 1962. Nesting of the dickcissel in Oklahoma. Auk 79:115-1 16.

Owens, R.A. and M.T. Myres. 1973. Effects of agriculture upon populations of native passerine birds of an Alberta fescue grassland. Can. J. Zool. 51:697-713.

Petrondas, D.A. and K. R.Gabriel. 1983. Multiple comparisons by rerandomization tests. J. Amer. Stat. Assoc. 78:949-957.

Reese, K.P. and J.T. Ratti. 1988. Edge effect: A concept under scrutiny. Tran. N. Amer. Wildl. Nat. Res. Conf. 53:127-136.

Renken, R.B. and J.L. Dinsmore. 1987. Nongame bird communities on managed grasslands in North Dakota. Can. Field Nat. 101:551-557.

Robel, R.J., J.N. Briggs, A.D. Dayton, and L.C. Hulbert. 1970. Relationships between visual obstruction measurements and weight of grassland vegetation. J. Range Manage. 23:295-297.

Robinson, W.L. and E.G. Bolen. 1984. Wildlife ecology and management. Macmillan Co., New York, N.Y.

Rotenberry, J.T. 1985. The role of habitat in avian community composition: physiognomy or floristics? Oecologia 67:213-217.

Rotenberry, J.T. and J.A. Wiens. 1980. Habitat structure, patchiness, and avian communities in North American steppe vegetation: A multivariate analysis. Ecol. 61:1228-1250.

Ryder, R.A. 1980. Effects of grazing on bird habitats, p. 51-66. In: R.M. DeGraff and N. G. Tilghman (compilers) Management of western forests and grasslands for nongame birds. USDA For. Serv., Intermountain For. and Range Exp. Stn., Gen. Tech. Rep. INT86. Ogden, Ut.

Slauson, W.L., B.S. Cade, and J.D. Richards. 1991. Blossom statistical software. Midcontinent Biological Science Center. National Biological Survey. Fort Collins, Colo.
South Dakota Ornithologists'Union. 1991. The birds of South Dakota, 2nd edition. Aberdeen, S.D.

Starfield, A.M. 1997. A pragmatic approach to modeling for wildlife management. J. Wildl. Manage. 61:261-270.

Steidl, R.J., J.P. Hayes, and E. Schauber. 1997. Statistical power analysis in wildlife research. J. Wildl. Manage. 61:270-279.

Tester, J.R. and W.M. Marshall. 1961. A study of certain plant and animal interrelations on a native prairie in northwestern Minnesota. Minnesota Mus. Nat. History Occ. Papers 8:1-51.

Uresk, D.W. 1990. Using multivariate techniques to quantitatively estimate ecological stages in a mixed grass prairie. J. Range Manage. 43:282-285.

USDA. 1987. Basic statistics 1982 national resources inventory. USDA, Soil Cons. Serv. Bull. No. 790.

USDA, NRCS. 1999. The PLANTS database (http://plants.usda.gov/plants). National Plant Data Center, Baton Rouge, La.

Wiens, J.A. 1969. An approach to the study of ecological relationships among grassland birds. Ornithological Monogr. 8:1-93.

Weins, J.A. 1973. Pattern and process in grassland bird communities. Ecol. Monogr. 43:237-270.

Weins, J.A. and J.T. Rotenberry. 1981. Habitat associations and community structure of birds on shrubsteppe environments. Ecol. Monogr. 51:21-41.

Wyckoff, A.M. 1986. A relict population of chestnut-collared longspurs in western Minnesota. Loon 58:3-11. 